\title{
Attitudes of Wisconsin State University System Librarians Towards the ALA Standards for College Libraries
}

A study was made to determine if the librarians in the Wisconsin State University System considered the ALA Standards for College Libraries to be primarily minimum model specifications for quality library service or goals toward which college libraries should strive. Regardless of the kind of library work they were in, their sex, or their tenure in their positions, the librarians queried predominantly favored the former interpretation of the Standards.

$\mathrm{T}$ ion among academic librarians in regard to the ALA Standards for College Libraries. ${ }^{1}$ Apparently, some librarians believe that the Standards should be implemented as soon as possible ${ }^{2}$ and the fact that they have not been adopted in many if not most college libraries ${ }^{3}$ should not affect their validity as minimal model specifications for quality library service. Other librarians, however, seem to regard the Standards as goals ${ }^{4}$ toward which college libraries should strive and which may be achieved sometime in the future, rather than as guidelines which

1 "ALA Standards for College Libraries," CRL, XX (July 1959), 274.

${ }^{2}$ Felix E. Hirsh, "How Can We Implement the Standards in College Libraries?" CRL, XXII (March 1961), 125-129.

3 "Adequacy of U.S. Library Services," ALA Bulletin, LVI (September 1962), 689.

"Sidney L. Jackson, letter in "Free for All," $A L A$ Bulletin, LVI (December 1962), 974.

Mr. Blankenship is Professor of Library Science, Wisconsin State Library, Whitewater. should be implemented immediately.

A study was recently made of the attitudes of librarians in the Wisconsin State University System to determine which of the two concepts described above more nearly coincided with them. Accordingly, the purpose of this paper is to report the findings of a survey of the attitudes of the librarians of these nine institutions.

The chief question with which the report is concerned may be stated in this form: "Do Wisconsin State University System librarians believe that the ALA Standards for College Libraries should

\section{TABLE 1}

Distribution of Responses to Two Statements and $\mathrm{X}^{2}$ TABle

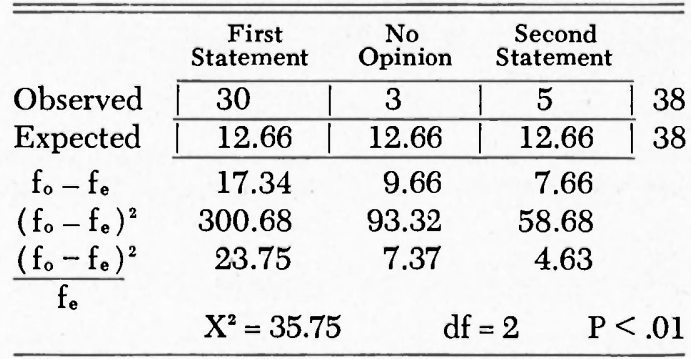


TABLE 2

\begin{tabular}{|c|c|c|c|c|c|c|}
\hline \multicolumn{7}{|c|}{$\begin{array}{l}\text { Statements Ranked According to Mean Value of Responses } \\
\text { Accompanied by Chi SQuare Tables }\end{array}$} \\
\hline \multicolumn{7}{|c|}{$\begin{array}{l}\text { 2. The faculty library committee should act strictly in an advisory capacity. (Mean response value } \\
=4.71 \text { ): }\end{array}$} \\
\hline \multirow{4}{*}{$\begin{array}{c}\text { Observed } \\
\text { Expected } \\
f_{o}-f_{n} \\
\left(f_{o}-f_{e}\right)^{2} \\
\left(f_{o}-f_{e}\right)^{2} \\
\end{array}$} & $\begin{array}{l}\text { Strongly } \\
\text { Agree }\end{array}$ & Agree & Undecided & Disagree & $\begin{array}{l}\text { Strongly } \\
\text { Disagree }\end{array}$ & \multirow{5}{*}{$\begin{array}{l}38 \\
38\end{array}$} \\
\hline & 28 & 9 & 1 & 0 & 0 & \\
\hline & 7.6 & 7.6 & 7.6 & 7.6 & 7.6 & \\
\hline & $\begin{array}{r}24.4 \\
401.60 \\
52.84\end{array}$ & $\begin{array}{l}1.4 \\
1.96 \\
.26\end{array}$ & \begin{tabular}{r}
\multicolumn{1}{c}{6.6} \\
43.56 \\
5.73
\end{tabular} & $\begin{array}{r}7.6 \\
57.76 \\
7.60\end{array}$ & $\begin{array}{c}7.6 \\
57.76 \\
7.60\end{array}$ & \\
\hline $\mathrm{f}_{\mathrm{e}}$ & $\mathrm{X}^{2}=74.03$ & & $\mathrm{df}=4$ & & & \\
\hline
\end{tabular}

10. Staff work areas should comprise 125 square feet of floor space per person. (Mean response value $=4.37$ ):

Observed

Expected

$f_{0}-f_{e}$

$\left(f_{o}-f_{e}\right)^{2}$

$\frac{\left(f_{o}-f_{e}\right)^{2}}{f_{e}}$

\begin{tabular}{|c|c|c|c|c|}
$\begin{array}{c}\text { Strongly } \\
\text { Agree }\end{array}$ & Agree & Undecided & Disagree & $\begin{array}{c}\text { Strongly } \\
\text { Disagree }\end{array}$ \\
\hline 19 & 15 & 3 & 1 & 0 \\
\hline 7.6 & 7.6 & 7.6 & 7.6 & 7.6 \\
\hline 11.4 & 7.4 & 4.6 & 6.6 & 7.60 \\
129.96 & 54.76 & 21.16 & 43.56 & 57.76 \\
17.10 & 7.20 & 2.78 & 5.73 & 7.60 \\
$\mathrm{X}^{2}=40.41$ & $\mathrm{df}=4$ & \multicolumn{2}{c|}{$\mathrm{P}<.01$} \\
\hline
\end{tabular}

3. Normally, the library should require a minimum of 5 per cent of the total educational and general budget of the institution. (Mean response value $=4.29$ ):

Observed

Expected

$\mathrm{f}_{\mathrm{o}}-\mathrm{f}_{\mathrm{e}}$

$\left(f_{o}-f_{e}\right)^{2}$

$\frac{\left(f_{o}-f_{e}\right)^{2}}{f_{e}}$

\begin{tabular}{|c|c|c|c|c|}
$\begin{array}{c}\text { Strongly } \\
\text { Agree }\end{array}$ & Agree & Undecided & Disagree & $\begin{array}{c}\text { Strongly } \\
\text { Disagree }\end{array}$ \\
\hline 21 & 10 & 5 & 1 & 1 \\
\hline 7.6 & 7.6 & 7.6 & 7.6 & 7.6 \\
\hline 13.4 & 3.4 & 2.6 & 6.6 & 6.6 \\
179.56 & 11.56 & 6.76 & 43.56 & 43.56 \\
23.62 & 1.52 & .89 & 5.73 & 5.73 \\
\multicolumn{2}{|c|}{$\mathrm{X}^{2}=37.49$} & $\mathrm{df}=4$ & \multicolumn{2}{c}{$\mathrm{P}<.01$}
\end{tabular}

8. For the development of college library collections, the following may serve as a guide: up to 600 students, 50,000 volumes; for every additional 200 students, 10,000 volumes . . . these are minimal figures. (Mean response value $=4.24$ ):

Observed

Expected

$f_{o}-f_{e}$

$\left(f_{o}-f_{e}\right)^{2}$

$\underline{\left(f_{o}-f_{e}\right)^{2}}$

\begin{tabular}{c|c|c|c|c|}
$\begin{array}{c}\text { Strongly } \\
\text { Agree }\end{array}$ & Agree & Undecided & Disagree & $\begin{array}{c}\text { Strongly } \\
\text { Disagree }\end{array}$ \\
\hline 18 & 14 & 4 & 1 & 1 \\
\hline 7.6 & 7.6 & 7.6 & 7.6 & 7.6 \\
\hline 10.4 & 6.4 & 3.6 & 6.6 & 6.6 \\
108.16 & 40.96 & 12.96 & 43.56 & 43.56 \\
14.23 & 5.39 & 1.70 & 5.73 & 5.73 \\
\multicolumn{2}{c}{$\mathrm{X}^{2}=32.78$} & $\mathrm{df}=4$ & \multicolumn{2}{c}{$\mathrm{P}<.01$} \\
\multicolumn{2}{c}{} & & \multicolumn{3}{c}{} \\
\hline
\end{tabular}

$f_{e}$ $\mathrm{X}^{2}=32.78$

$\mathrm{df}=4$ 


\section{4 / College \& Research Libraries • March 1968}

1. The librarian should be responsible directly to the president. (Mean response value $=4.18$ ):

Observed

Expected

$f_{0}-f_{e}$

$\left(f_{o}-f_{e}\right)^{2}$

$\underline{\left(f_{0}-f_{0}\right)^{2}}$

\begin{tabular}{|c|c|c|c|c|}
\hline $\begin{array}{l}\text { Strongly } \\
\text { Agree }\end{array}$ & Agree & Undecided & Disagree & $\begin{array}{l}\text { Strongly } \\
\text { Disagree }\end{array}$ \\
\hline 21 & 8 & 5 & 3 & 1 \\
\hline 7.6 & 7.6 & 7.6 & 7.6 & 7.6 \\
\hline 13.4 & .4 & 2.6 & 4.6 & 6.6 \\
\hline 179.56 & .16 & 6.76 & 21.16 & 43.56 \\
\hline 23.62 & .02 & .89 & 2.78 & 5.73 \\
\hline \multicolumn{2}{|c|}{$X^{2}=33.04$} & $\mathrm{df}=4$ & \multicolumn{2}{|c|}{$\mathrm{P}<.01$} \\
\hline
\end{tabular}

7. The library of a college enrolling 600 students cannot be expected to give effective support to the instructional program if it contains fewer than 50,000 carefully chosen volumes. (Mean response value $\mathbf{=} .13$ ):

Observed

Expected

$f_{o}-f_{e}$

$\left(f_{0}-f_{0}\right)^{2}$

$\underline{\left(f_{o}-f_{e}\right)^{2}}$

$f_{0}$

\begin{tabular}{|cccccc|c|}
$\begin{array}{c}\text { Strongly } \\
\text { Agree }\end{array}$ & Agree & Undecided & Disagree & \multicolumn{1}{c}{$\begin{array}{c}\text { Strongly } \\
\text { Disagree }\end{array}$} \\
\hline 17 & 13 & 1 & 4 & 4 & 0 \\
\hline 7.6 & 7.6 & 7.6 & 7.6 & 7.6 \\
\hline 9.4 & 5.4 & 3.6 & 3.6 & 7.6 \\
88.36 & 29.16 & 12.96 & 12.96 & 57.76 \\
11.63 & 3.84 & 1.70 & 1.70 & 7.60 \\
$\mathrm{X}^{2}=34.07$ & $\mathrm{df}=4$ & \multicolumn{2}{c|}{$\mathrm{P}<.01$} \\
\end{tabular}

5. For a college library three professional librarians constitute the minimum number required for effective service; i.e. the chief librarian and the staff members responsible for readers' services and technical processes. (Mean response value $=4.10$ ):

Observed

Expected

$f_{0}-f_{0}$

$\left(f_{o}-f_{e}\right)^{2}$

$\frac{\left(f_{o}-f_{e}\right)^{2}}{f_{0}}$

\begin{tabular}{|c|c|c|c|c|}
$\begin{array}{c}\text { Strongly } \\
\text { Agree }\end{array}$ & Agree & Undecided & Disagree & \multicolumn{1}{c|}{$\begin{array}{c}\text { Strongly } \\
\text { Disagree }\end{array}$} \\
\hline 18 & 12 & 3 & 4 & 1 \\
\hline 7.6 & 7.6 & 7.6 & 7.6 & 7.6 \\
\hline 10.4 & 4.4 & 4.6 & 3.6 & 6.6 \\
108.16 & 19.36 & 21.16 & 12.96 & 43.56 \\
14.23 & 2.55 & 2.78 & 1.70 & 5.73 \\
\multicolumn{2}{|c|}{$\mathrm{X}^{2}=26.99$} & $\mathrm{df}=4$ & \multicolumn{2}{c}{$\mathrm{P}<.01$} \\
\end{tabular}

9. The college library should be large enough to provide seating for at least one-third of the student body. (Mean response value $=4.03)$ :

Observed

Expected

$f_{0}-f_{e}$

$\left(f_{0}-f_{0}\right)^{2}$

$\underline{\left(f_{0}-f_{e}\right)^{2}}$

\begin{tabular}{|c|c|c|c|c|}
\hline $\begin{array}{l}\text { Strongly } \\
\text { Agree }\end{array}$ & Agree & Undecided & Disagree & $\begin{array}{l}\text { Strongly } \\
\text { Disagree }\end{array}$ \\
\hline 11 & 21 & 2 & 4 & 0 \\
\hline 7.6 & 7.6 & 7.6 & 7.6 & 7.6 \\
\hline 3.4 & 13.4 & 5.6 & 3.6 & 7.6 \\
\hline 11.56 & 179.56 & 31.36 & 12.96 & 57.76 \\
\hline 1.52 & 23.63 & 4.13 & 1.70 & 7.60 \\
\hline
\end{tabular}

11. Table space of $3^{\prime} \times 2^{\prime}$ per reader is recommended for general library use. (Mean response value $=3.89$ ):

Observed

Expected

$f_{0}-f_{0}$

$\left(f_{0}-f_{0}\right)^{2}$

$\frac{\left(f_{o}-f_{e}\right)^{2}}{f_{e}}$

\begin{tabular}{|c|c|c|c|c|}
$\begin{array}{c}\text { Strongly } \\
\text { Agree }\end{array}$ & Agree & Undecided & Disagree & $\begin{array}{c}\text { Strongly } \\
\text { Disagree }\end{array}$ \\
\hline 13 & 15 & 4 & 5 & 1 \\
\hline 7.6 & 7.6 & 7.6 & 7.6 & 7.6 \\
\hline 5.4 & 7.4 & 3.6 & 2.6 & 6.6 \\
29.16 & 54.76 & 12.96 & 6.76 & 43.56 \\
3.84 & 7.20 & 1.70 & .89 & 5.73 \\
$\mathrm{X}^{2}=19.36$ & $\cdot \mathrm{df}=4$ & \multicolumn{2}{c|}{$\mathrm{P}<.01$}
\end{tabular}


6. At least one professional librarian should be on duty at all times during which the library is open for full service. $($ Mean response value $=3.79$ ):

Observed

Expected

$f_{o}-f_{e}$

$\left(f_{o}-f_{e}\right)^{2}$

$\underline{\left(f_{0}-f_{e}\right)^{2}}$

\begin{tabular}{c|c|c|c|c|c|}
$\begin{array}{c}\text { Strongly } \\
\text { Agree }\end{array}$ & Agree & \multicolumn{2}{c}{ Undecided } & Disagree & $\begin{array}{c}\text { Strongly } \\
\text { Disagree }\end{array}$ \\
\hline 18 & 5 & 6 & 7 & 2 \\
\hline 7.6 & 7.6 & 7.6 & 7.6 & 7.6 \\
\hline 10.4 & 2.6 & 1.6 & .6 & 5.6 \\
108.16 & 6.76 & 2.56 & .36 & 31.36 \\
14.23 & .89 & .34 & .05 & 4.13 \\
\multicolumn{2}{c}{$\mathrm{X}^{2}=19.64$} & $\mathrm{df}=4$ & \multicolumn{2}{c}{$\mathrm{P}<.01$} \\
\end{tabular}

4. Experience shows that a good college library usually spends twice as much (or more) for salaries as it does for books. (Mean response value $=3.74$ ):

Observed

Expected

$f_{o}-f_{o}$

$\left(f_{o}-f_{e}\right)^{2}$

$\underline{\left(f_{o}-f_{e}\right)^{2}}$

$f_{e}$

\begin{tabular}{|c|c|c|c|c|}
$\begin{array}{c}\text { Strongly } \\
\text { Agree }\end{array}$ & Agree & Undecided & Disagree & $\begin{array}{c}\text { Strongly } \\
\text { Disagree }\end{array}$ \\
\hline 10 & 15 & 9 & 1 & 3 \\
\hline 7.6 & 7.6 & 7.6 & 7.6 & 7.6 \\
\hline 3.4 & 8.4 & 2.4 & 6.6 & 4.6 \\
11.56 & 70.56 & 5.76 & 43.56 & 21.16 \\
1.52 & 9.28 & .76 & 5.73 & 2.78 \\
\multicolumn{2}{|c|}{$\mathrm{X}^{2}=20.07$} & $\mathrm{df}=4$ & \multicolumn{2}{c|}{$\mathrm{P}<.01$} \\
\multicolumn{2}{r}{}
\end{tabular}

serve as minimal, model specifications for the evaluation of college libraries which should be implemented immediately if at all possible?"

To test the question, schedules were sent to the sixty-three librarians who were associated with the Wisconsin State University System late in 1965. Thirtyeight were returned, which made a return rate of 60.32 per cent. The schedules included the two statements below, and the respondents were asked to check the one which more nearly agreed with their conception of the Standards.

I believe that the Standards should serve primarily as minimal model specifications for the evaluation of college libraries and should be implemented immediately if at all possible.

I believe that the Standards should serve primarily as goals toward which college libraries should strive, and that immediate implementation is not necessary.

Thirty respondents checked the first statement. Five checked the second statement, and three people were undecided. Table 1 indicates the distribution and the statistical analysis of this distribution by chi square, although by inspection it appears to be obvious that there is a significant difference in the responses.

From the responses above, it would seem that the majority of the Wisconsin State University System librarians regard the ALA Standards for College Libraries as minimal model specifications for the evaluation of college libraries, which should be implemented immediately if at all possible and that the chief question of the survey is answered in the affirmative.

To further test their attitudes, the librarians were requested to evaluate eleven additional statements which were taken or paraphrased from the Standards. Agreement or disagreement was indicated by the respondent checking one of five answers: Strongly agree, agree, undecided, disagree, or strongly disagree. Numerical values assigned to the answers ranged from one to five; one for strongly disagree through five for strongly agree. The statements were ranked according to the mean value of the weighted responses and appear in 
Table 2 together with the statistical analyses.

It is true that chi square indicates direction only. However, an inspection of Table 2 indicates that the responses to all eleven statements fell primarily in the strongly agree and agree cells, thus the chi square values would indicate that the librarians are in agreement with these facets of the Standards. Therefore it is believed that these responses support further the findings of the choice between the two main statements, which differentiated between the Standards as minimal guidelines to be implemented immediately or as goals to be achieved in the future.

It is also interesting to note how the librarians as a whole reacted to the individual statements. According to the numerical value of the responses, the librarians agreed more strongly with the following statement than with any of the others: "The faculty library committee should act strictly in an advisory capacity."

They also indicated a high rate of agreement that staff work areas should consist of at least 125 square feet per person and that the college library should receive a minimum of five per cent of the total institutional budget.

As a whole, the librarians indicated the smallest degree of agreement to the following statement than with the other ten: "Experience shows that a good college library spends twice as much (or more) for salaries as it does for books."

The questionnaires also requested other data, and this part of the paper will consist of analyzing the responses to the eleven statements listed above when the librarians are grouped according to professional areas of service. Accordingly, an attempt will be made to prove or disprove the following statements. "There is no significant difference in the attitudes of Wisconsin State University System librarians toward selected
TABLE 3

Analysis of Variance Among Means of Responses of Three Groups of Librarians

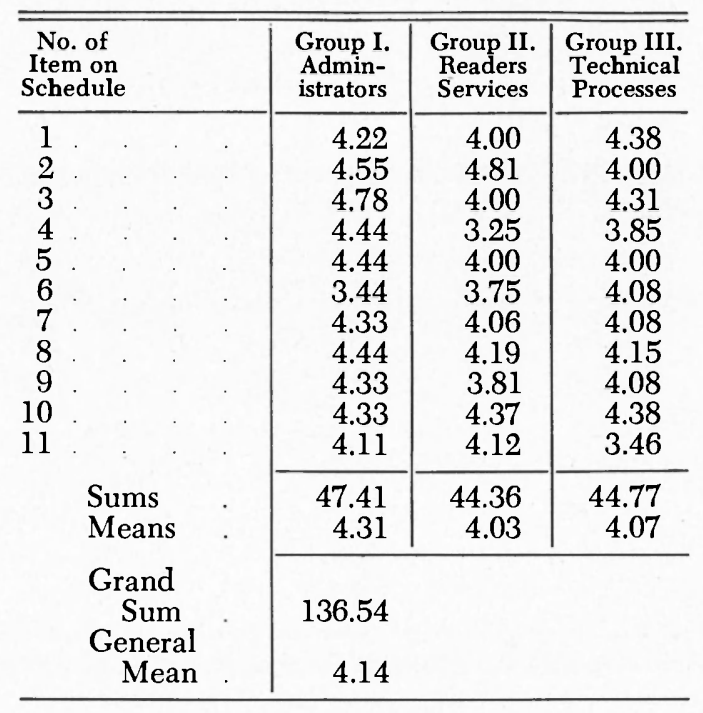

Analysis of Variance Computation:

A. Calculation for Sums of Squares

1. Correction Term (C) $=\frac{(136.54)^{2}}{33}$ $=\frac{18,643.17}{33}=564.94$

2. Total Sum of Squares $=(4.22)^{2}+$ $(4.55)^{2} \ldots(4.38)^{2}+(3.46)^{2}-\mathrm{C}=$ $568.75-564.94=3.81$

3. Sum of Squares Among Means $=$ $\frac{(47.41)^{2}+(44.36)^{2}+(44.77)^{2}}{11}-\mathrm{C}=$ $565.44-564.94=.50$

4. Sum of Squares Within $=3.81-.50=$ 3.31

B. Analysis of Variance

\begin{tabular}{lrrl} 
Source & df & \multicolumn{1}{c}{ SS } & MS \\
\hline Among & 2 & .50 & .25 \\
Within & 30 & 3.31 & .10 \\
\hline Total & 32 & 3.81 & \\
F $=\frac{.50}{3.31}=.15 \mathrm{P}<.01$ &
\end{tabular}

aspects of the ALA Standards when they are grouped according to the following professional areas of service: administration, public services, or technical processes."

When asked to identify their profes- 
sional areas of interest, nine respondents stated administration; sixteen were engaged in readers' services; and the remaining thirteen were working in the technical processes areas.

In order to test the null hypothesis, the means of the numerical values of the responses to each of the eleven statements taken or paraphrased from the ALA Standards were determined for each of the three groups, and these values were subjected to an analysis of variance. An inspection of Table 3 will indicate that all means indicated agreement with the statements since all values were above 3.00 . The analysis of variance computation yielded an $\mathrm{F}$ of .15 which indicates that, at the .01 level, there is no significant difference in the value attitudes of Wisconsin State University System librarians when they are grouped according to their professional areas of service as administrative, public service, or technical processes librarians.

Since it appears that there is little question that the ALA Standards are accepted by a significant number of the respondents, there seemed little point in applying the same statistical tests to the remaining data. Therefore, it was decided to compute correlations from rank differences in the responses of the librarians when grouped according to age, tenure, and sex.

Accordingly, an attempt was made to test the following statement: "There is no significant difference in the rank orders of the statements representing facets of the ALA Standards assigned by librarians over forty years of age when correlated with the ranks assigned by librarians under forty years of age."

The means of the weighted responses for each of the two groups of librarians described above were determined, and Table 4 lists the abridged statements in ranks.

The rho calculation indicates that the two groups differ somewhat in the intensity of their agreement with the state-

TABLE 4

Rank Order of Mean Responses Assigned to Statements by Librarians Grouped According to Age, Tenure, and Sex

\begin{tabular}{|c|c|c|c|c|c|}
\hline \multirow[b]{2}{*}{$\begin{array}{l}\text { No. OF } \\
\text { STATE- } \\
\text { MENT }\end{array}$} & \multirow[b]{2}{*}{ ABRidGED Statement } & \multicolumn{4}{|c|}{ AGE } \\
\hline & & $\begin{array}{r}\text { Group I } \\
\text { Under 40 } \\
\text { Yrs. of Age } \\
\end{array}$ & $\begin{array}{r}\text { Group II } \\
\text { Over 40 } \\
\text { Yrs. of Age }\end{array}$ & D & $\mathrm{D}^{2}$ \\
\hline \multirow{12}{*}{$\begin{array}{r}2 \\
10 \\
1 \\
3 \\
8 \\
7 \\
7 \\
9 \\
11 \\
5 \\
6 \\
4\end{array}$} & Library committee act in advisory capacity & 1 & 1 & 1.0 & 1.00 \\
\hline & Work-areas 125 square feet per person. & 2 & 6 & 4.0 & 16.00 \\
\hline & Librarian directly responsible to president & 3 & 8 & 5.0 & 25.00 \\
\hline & Library requires $5 \%$ of budget & 4.5 & 2 & 2.5 & 6.25 \\
\hline & $\begin{array}{l}\text { Up to } 600 \text { students, } 50,000 \text { volumes in } \\
\text { collection }\end{array}$ & 4.5 & 4.5 & .0 & 00 \\
\hline & Support instruction, 50,000 volumes in & & & & \\
\hline & Library should seat one-third students & 7 & $\begin{array}{l}4.5 \\
7\end{array}$ & $\begin{array}{r}2.5 \\
.0\end{array}$ & $\begin{array}{r}0.25 \\
.00\end{array}$ \\
\hline & $\begin{array}{l}\text { Table space of } 3^{\prime} \times 2^{\prime} \text { per reader is } \\
\text { recommended }\end{array}$ & 7 & 9 & 2.0 & 4.00 \\
\hline & Three professional librarians compose & & & & \\
\hline & minimum staff & $\begin{array}{l}9.5 \\
9.5\end{array}$ & 3 & $\begin{array}{l}6.5 \\
1.0\end{array}$ & $\begin{array}{r}42.25 \\
1.00\end{array}$ \\
\hline & Twice as much money for salaries as for & & & & \\
\hline & books & 11 & 10.5 & .5 & .25 \\
\hline & & \multicolumn{4}{|c|}{$\Sigma D^{2}=102.00$} \\
\hline & Rho Computation & \multicolumn{4}{|c|}{ Rho $=1-\frac{6 \Sigma D^{2}}{N\left(n^{2}-1\right)}=.54$} \\
\hline
\end{tabular}


ments; indeed if Garrett ${ }^{5}$ is correct that the correlation of .54 is not significant at the .05 level, the null hypothesis is not sustained.

Apparently the younger group feels that it is more important that the librarian report directly to the president than does the older one, and the older group apparently believes that it is more important to have a minimum of three professional librarians than do the younger librarians.

The second category in which the librarians were placed was that of tenure. As the term is used here, tenure equals the number of years that an individual had spent in library service. Twenty-two of the respondents had fewer than fifteen years of service while sixteen had been librarians for more than fifteen years.

Tenure presents much the same pic-

5 Henry E. Garrett, Statistics in Psychology and Education (5th ed., New York: David McKay Company, 1958), p. 201; 275. ture as age, a positive correlation of .56 which again is not significant at the .05 level. Therefore, it may be concluded that while Wisconsin State University System librarians agree with the statements taken or paraphrased from the ALA Standards, the intensity of agreement is not sufficient to produce a significant rank order of correlation, when the statements are arranged according to their weighted responses of librarians grouped according to length of service.

The greatest differences in rank were found in the same statements which were noted for age.

The responses of male and female librarians were also ranked in order of weighted responses in order to test the following statement: "There is no significant difference in the rank orders of the statements representing facets of the ALA Standards assigned by female librarians when correlated with the ranks assigned by male librarians."

The means of the weighted responses

TABLE 4 (Cont.)

Rank Order of Mean Responses Assigned to Statements by Librarians Grouped According to Age, Tenure, and Sex

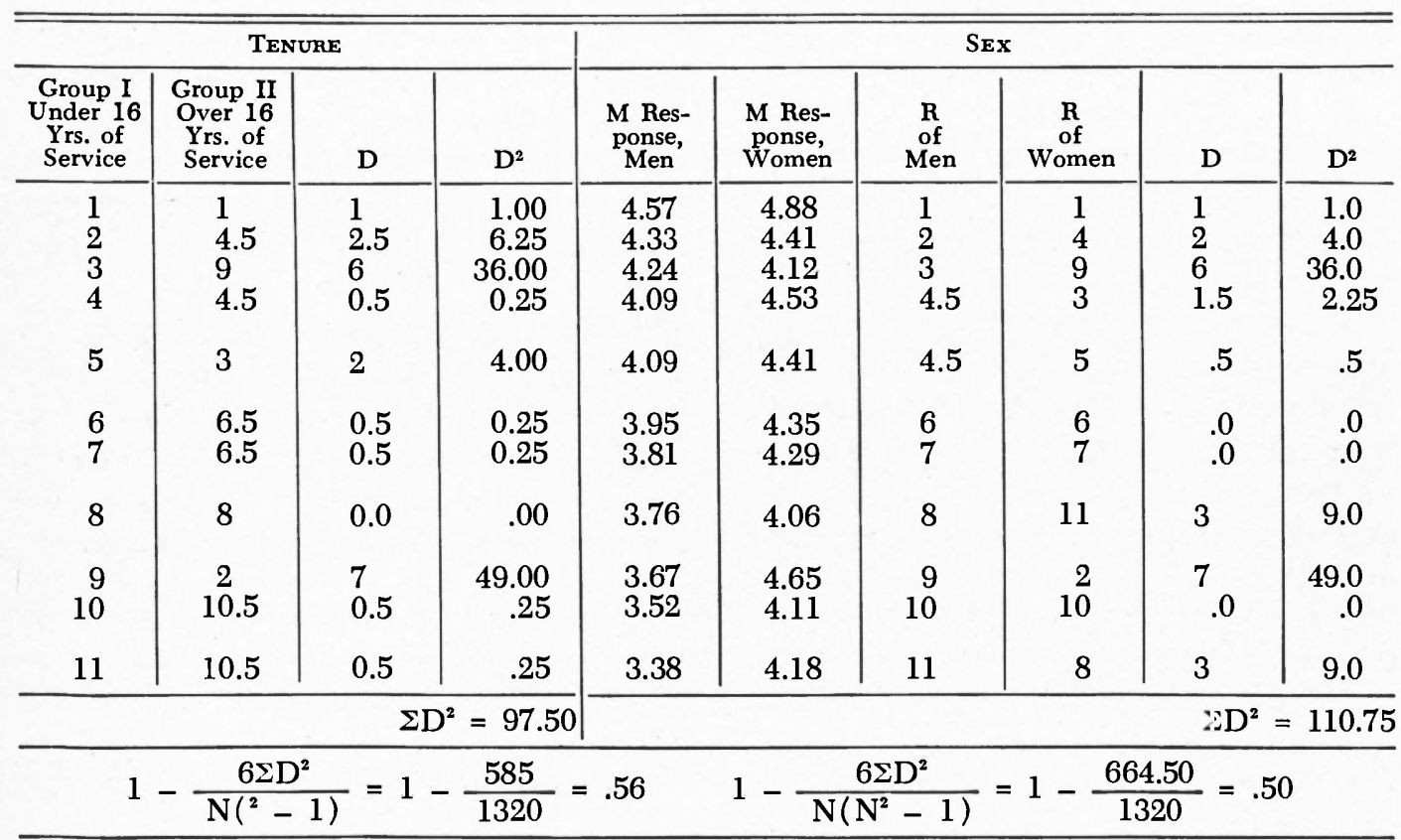


for each of these two groups of Wisconsin State University System librarians were calculated and ranks were assigned to the statements. Table 4 also lists the ranked abridged statements, together with the mean responses for the seventeen women and twenty-one men. As was true of age and tenure the intensity of agreement with the standards differed, and the correlation of .50 was the lowest of the three. It was, of course, not significant. Thus we may conclude that, while men and women both agree with the statements, they do not necessarily agree to the same degree with the same statement. Women apparently feel more strongly than men that three professional librarians should be the absolute minimum number of staff members, but they feel much less strongly about the librarian being responsible to the president.

An inspection of Table 4 also indicates that for every mean value response by men the equivalent for women was higher except in the case of one statement; the one stating that the librarian should be responsible to the president. These responses may indicate that, while librarians of both sexes agree with the statements, the females tend to agree more strongly.

\section{SUMMARY}

An opinion survey concerning the ALA Standards for College Libraries was sent to sixty-three Wisconsin State University System librarians in 1965. Thirty-eight schedules, 60.32 per cent of the total were returned. When asked to check one of two statements which more nearly agreed with their concept of the Standards, thirty librarians, or 79 per cent of the respondents, checked the first of the two following statements:

1. I believe that the Standards should serve primarily as minimal model specifications for the evaluation of college libraries and should be im- plemented immediately if at all possible.

2. I believe that the Standards should serve primarily as goals toward which college libraries should strive, and that immediate implementation is not necessary.

Five, or 13 per cent of the respondents, checked the second statement and three respondents did not answer. From this evidence, it would seem that Wisconsin State University System librarians believe that the Standards are not goals but minimal specifications for college library service and should be implemented immediately.

To further test the attitudes of the librarians, eleven statements representing specific aspects of the Standards were also placed on the schedules and the respondents were requested to check one of five categories to indicate their degree of agreement or disagreement for each item. The categories were as follows: strongly agree, agree, undecided, disagree, and strongly disagree. A numerical scale, which ranged from a value of five for strongly agree down to one for strongly disagree, was used to assign numerical values and to compute means from the weighted responses.

The data were coded and placed on punched cards, and computations were made by using the equipment of the Computing Center at Wisconsin State University-Whitewater.

Table 2 indicates that a significant number of the respondents agreed with the statements taken from the Standards. When the frequencies of the responses to the statements were subjected to chi square tests, it was found that the differences between the agreement and disagreement responses were significant at the .01 level for all of the eleven statements representing aspects of the ALA Standards for College Libraries.

The schedules also yielded additional information such as the area of librarian- 
ship in which the rspondents were engaged, the sex of the respondents, their approximate ages, and the number of years that the individuals had been in library service.

When the responses of administrative, readers' services, and technical processes librarians were subjected to an analysis of variance, an $\mathrm{F}$ value of .15 indicated that there was no significant difference in the mean values of the responses among the three groups. Thus it is believed that Wisconsin State University System librarians do not differ significantly in their attitudes toward selected aspects of the ALA Standards when these individuals are grouped according to the area of librarianship in which they practice.

The rank difference method of correlation was used to analyze the responses of the Wisconsin State University System librarians when they were grouped according to age, tenure, and sex.

It was found that there was a positive rank order of correlation: (a) between the responses of librarians over forty years of age and those under forty; (b) between the responses of librarians having over sixteen years of service and those having fewer than sixteen; and (c) between the responses of men and the responses of women. In all cases, a significant number of the librarians agreed with the statements, but the intensity of agreement did not indicate that the rho's were significant.

It is interesting to note that from an inspection of Table 4 , the female librarians apparently were more strongly in agreement with the statements taken or paraphrased from the Standards than were the men.
From the data above, it would appear that the following generalizations might have a factual basis:

1. A significant number of Wisconsin State University System librarians believe that the ALA Standards for College Libraries should serve as minimal model specifications for the evaluation of college libraries and should be implemented immediately if at all possible.

2. Apparently, there is no significant difference in the attitudes of Wisconsin State University System librarians toward the ALA Standards for College Libraries, when they are grouped according to their professional areas: administration, readers' services, and technical processes.

3. Rank orders of correlation indicate that librarians over forty years of age, librarians who have been active in the profession for more than sixteen years, and librarians who are women tend to agree more strongly with the ALA Standards than the corresponding groups of librarians. The rho's also indicated that while a significant number of librarians agree with the ALA Standards, they vary in intensity of agreement in their responses to statements representing various aspects of the Standards.

Perhaps the chief value of this report is its indication of the strong support of the ALA Standards by this particular group of college librarians, but one should not fail to notice that there is a minority who think of the Standards as goals rather than as guides for quality library service. 